\title{
ANALYSIS OF CRUISE SHIP TRAFFIC IN THE PORT OF SPLIT
}

\author{
Tina Perić1*, Vice Mihanović ${ }^{2}$, Ivana Golub Medvešek ${ }^{1}$ \\ ${ }^{1}$ University of Split, Faculty of Maritime Studies, Croatia \\ ${ }^{2}$ Split Port Authority, Croatia
}

Cruise ship traffic is a part of a shipping industry, which is growing constantly both in number of ships and their capacity. Port of Split is second largest cruise port in the Croatia. Many analyses were made for the city of Dubrovnik and some measures for improvement as a result have already been taken. The goal of this paper is to provide detailed analyses of cruise ship traffic in Port of Split as a basis for a future research of carrying capacity of Split's cruise tourism in aspect of sustainable development.

Key words: Port of Split, cruise traffic, cruise ship

\section{INTRODUCTION}

Since the early days of the development of cruise ships, the demand for this type of tourism has been increasing continuously, leading to building mega cruisers, larger than many cities. Today, the number of passengers on cruise ships is around 30 million a year, with a steady growth rate of seven percent annually. In Croatia, that number is around a million out of which about one quarter is in Split.

Split is the largest passenger ferry port in Croatia and therefore has a vital role in organizing and conducting maritime transport, especially since it is connected through the City Port to a significant part of Croatia's archipelagos: Brač, Šolta, Hvar, Vis, Korčula, and Lastovo. There are large oscillations in maritime transport during the year, because most of the maritime transport takes place during the summertime - over $60 \%$ in two summer months [1]. This is also the time when cruise tourism in Split is at its peak. With two new berths for large cruise ships, some relief has come in terms of Port space but the number of passengers is constantly increasing leaving the problem of carrying passenger capacity of the city together with the problem of crowding and congestion in the town centre.

\section{CRUISE SHIP INDUSTRY}

The cruise industry has been continuously growing since the 1970s and is considered to be the fastest-growing travel vacation segment ever [2]. Growth of cruise ship tourism in general is impressive - demand for cruising increased almost $50 \%$ in five-year period from $2000-2005$ [3] and then again by $50 \%$ in nine-year period from 2005 to 2014 and at last $20.5 \%$ in the last five years [4]. In 2015 the total economic impact of the global cruise industry was the generation of US\$117 billion and opening of almost 957 thousand jobs, paying US $\$ 38$ billion in wages and salaries [5].

\section{Cruise ship traffic}

At the beginning of 2010 world merchant fleet had 291 cruise ship with 15.2 mil. BT and the average size of 54,047 BT [3] and at the beginning of 2018 there were 369 cruise ships with 550,000 berths [6]. Cruise ships are generally large ships. While they represent only $18 \%$ in total number of passenger vessels at the same time, they represent $93 \%$ in total BT of passenger vessels [7]. The cruise ship order book from 2018-2025 includes 50 new ocean-going vessels with average capacity of 4000 passengers [4] so the growth of cruise fleet is expected to continue in the same manner. Fig. 1 presents number of passengers on oceangoing cruise ships in last 20 years worldwide.

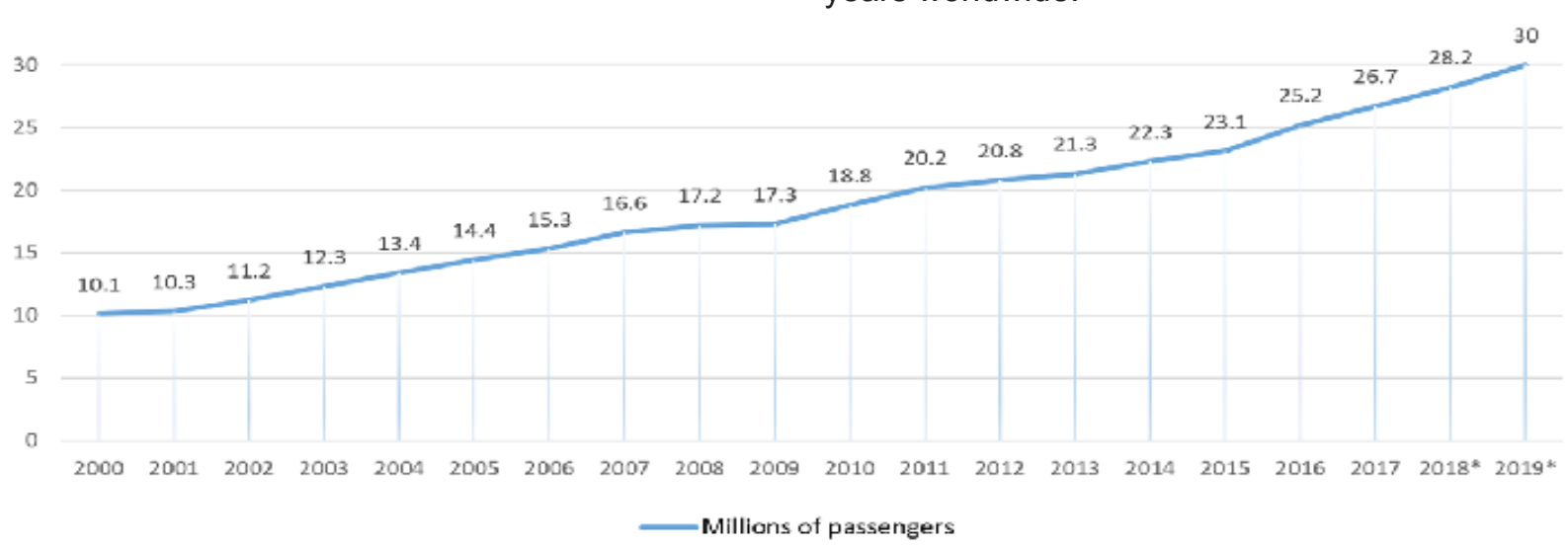

Figure 1: World ocean cruise passengers in the past 20 years [8] 
The Mediterranean and its adjoining seas has been one of the most dynamic cruise regions of the world in recent times. The share of the Mediterranean traffic increased from $12,9 \%$ in 2006 to $15,8 \%$ in 2017 and as a result, the Med stands today as the second biggest cruising region of the world, following Caribbean [6]. There are four regions in the Mediterranean cruise area shown in Fig. 2. out of which Adriatic Sea is second most visited. In Mediterranean cruise traffic Republic of Croatia is $6^{\text {th }}$ in number of passengers with $4.5 \%$ of total passengers and 5 th in number of arrivals with $8.2 \%$ of total cruise calls [6].

\section{Cruise ships}

In the modern world of cruising ships come in every shape and size, from the 2,298 tons Star Clipper to the 228,081 tons Symphony ofthe Seas, Fig.3. Not everyone wants to be on a ship that offers everything and more, some people prefer mid-sized ships with a good variety of entertainment and spa treatments, and others prefer smaller, stripped down ships that concentrate on the destination. There are different approaches to defining the size of a ship, but the most commonly used is the one by which the size is defined by the ship's passenger capacity and the gross tonnage of the ship.

The full/average cruise ship passenger capacity is based on double occupancy (2 guests per cabin) but cabin's capacity varies according to stateroom's type, category, and also by line and ship. A standard passenger cabin on cruise ships usually accommodates 2 to 4 guests. Max (largest) passenger capacity of a cruise ship would signify this ideal financial situation when all the berths, plus all upper and lower bunks, "Pullman" beds and single and double sofa are all occupied. A list of all cruise ships with their average and max passenger capacity is available online [9].

Accordingly, cruise ships based on their size can be divided into five classes:

- very small cruise ships - less than 10,000 tons and less than 200 passengers,
- $\quad$ small cruise ships - with 10,000-19,999 tons and 200-500 passengers,

- $\quad$ medium cruise ships - with 20,000-49,999 tons and 500-1,200 passengers,

- $\quad$ large cruise ships - with 50,000-69,999 tons and 1,200-2,000 passengers and

- mega cruise ships - with more than 70,000 tons and more than 2,000 passengers.

Cruise ships are part of cruise lines. A cruise line is a passenger shipping company operating privately-owned, parent-owned or chartered vessels. Currently, there are 33 cruise lines (small cruise lines and river cruise lines not included) out of which two are newly founded and not operating yet (waiting for delivery of their first ships). These cruise lines operate 274 cruise ships with 36 more, currently under construction and coming to market in 2019-2022. If distributed into classes, there are 16 very small, 22 small, 38 medium, 49 large and 149 mega cruise ships.

Most brands have unique activities and signature amenities offered exclusively onboard its vessels. According to the quality and price of their product, cruise lines are classified in 4 classes [9]:

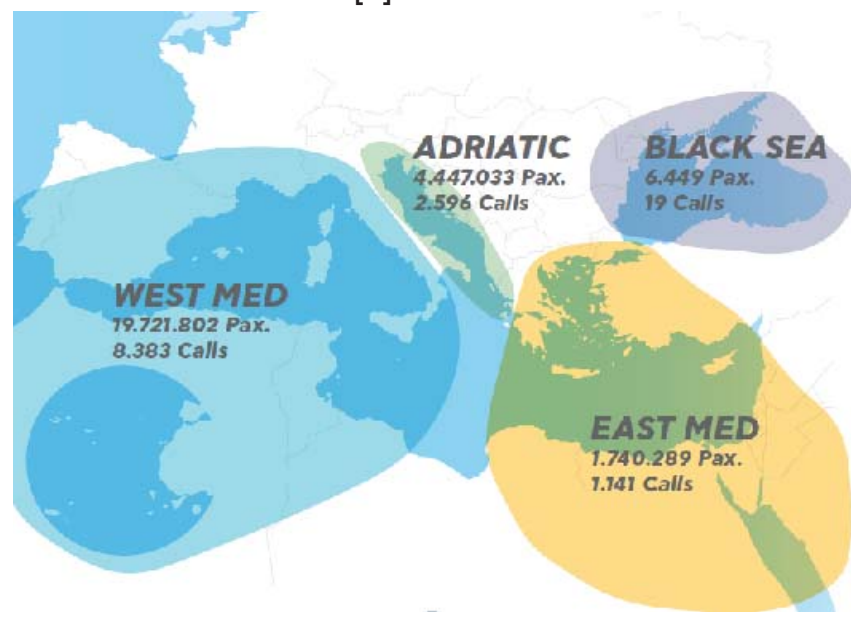

Figure 2: Cruise Traffic distributionin Mediterranean Region in 2017 [6]

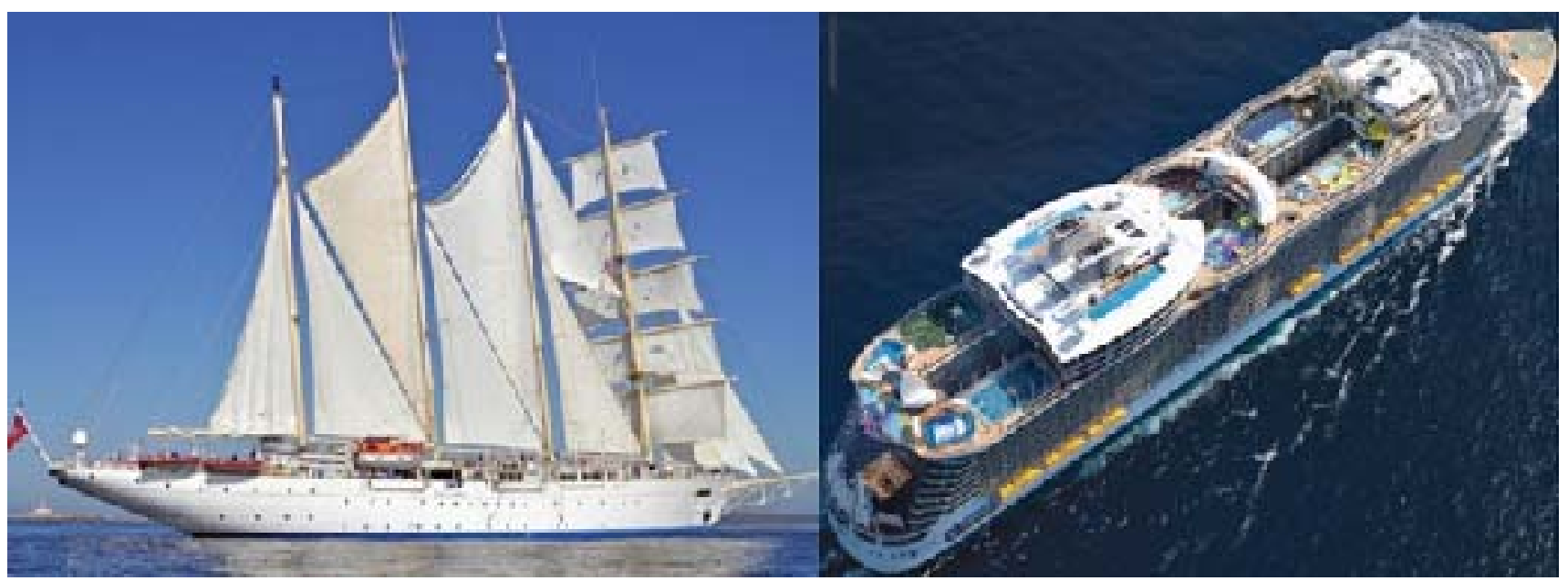

Figure 3: Variety of cruise ship offer (Star Clipper on left and Symphony of the Seas on the right side)[9] 
- Cheapest cruise lines (aka mass-market, mainstream) - offer good product at affordable prices. Fares range from $\$ 50-300$ per person per day. Ships are large-sized (over 3000 passengers), providing large resort-like experience. Examples include Carnival, Royal Caribbean, NCL, MSC, Costa, Holland America, AIDA, TUI.

- $\quad$ Budget cruise lines - fares range from \$200-500 per person per day. Examples include NCL, Disney, Celebrity, Princess, Star Cruises, Marella, P\&O, Pullmantur, Phoenix Reisen, Fred Olsen, Cruise and Maritime Voyages, Bahamas Paradise.

- Luxury cruise lines are Viking Ocean, Dream Cruises, Cunard, Oceania, Hapag-Lloyd, Ponant, Saga. Services are premium (including 24-hour highly personalized concierge), prices are affordable, ships are new (refurbished more often), but the product is not all-inclusive.

- All-inclussive cruise lines are Seabourn, Silversea, Regent, Azamara, Crystal, Virgin Voyages, Norwegian Yacht Voyages, Ritz-Carlton Yachts, Seadream Yachts. Onboard product is industry's best and includes 24-hour personal butler service, all beverages, specialty dining, Internet, shore excursions, gratuities, flights, transfers... Vessels are mid-sized (mega-yachts) with capacity between $200-1000$ passengers.

\section{CRUISE SHIP TRAFFIC IN PORT OF SPLIT}

The port of Split is the largest Croatian passenger port, with around 5 million passengers per year [10], while according to the statistical data it is ranked third among the ports of the Mediterranean [1]. However, only around 280,000 are passengers from cruise ships, which makes Split the second most important cruise port in Croatia, just behind Dubrovnik. In perspective of cruise passenger traffic in the Adriatic Sea Split is $6^{\text {th }}$ with $15 \%$ of Adriatic cruise passenger traffic while Dubrovnik is $2^{\text {nd }}$ with $16 \%$ [2]. In perspective of cruise passenger traffic in Mediterranean Sea Split is $29^{\text {th }}$ and Dubrovnik is $12^{\text {th }}$ [6] and in perspective of cruise passenger traffic in Europe Split is $49^{\text {th }}$ and Dubrovnik is $16^{\text {th }}$ [11].

\section{Port of Split}

The town of Split lies on the Adriatic coast, central Dalmatia. It is the administrative centre of the Split-Dalmatia County. With population of 178,192 (according to the latest census conducted in 2011) the city is ranked the country's second largest - following the capital Zagreb. Since 1979 the entire historical core of Split with Diocletian's palace has been listed as UNESCO World Heritage.

The term Port of Split is usually allocated with City Port Basin, Fig. 4, which is located at latitude of 43030,0' N and longitude of $016^{\circ} 26,2^{\prime} \mathrm{E}$ with $16.7 \mathrm{~km}^{2}$ of sea area and $0.10 \mathrm{~km}^{2}$ of land area. However, there are six more

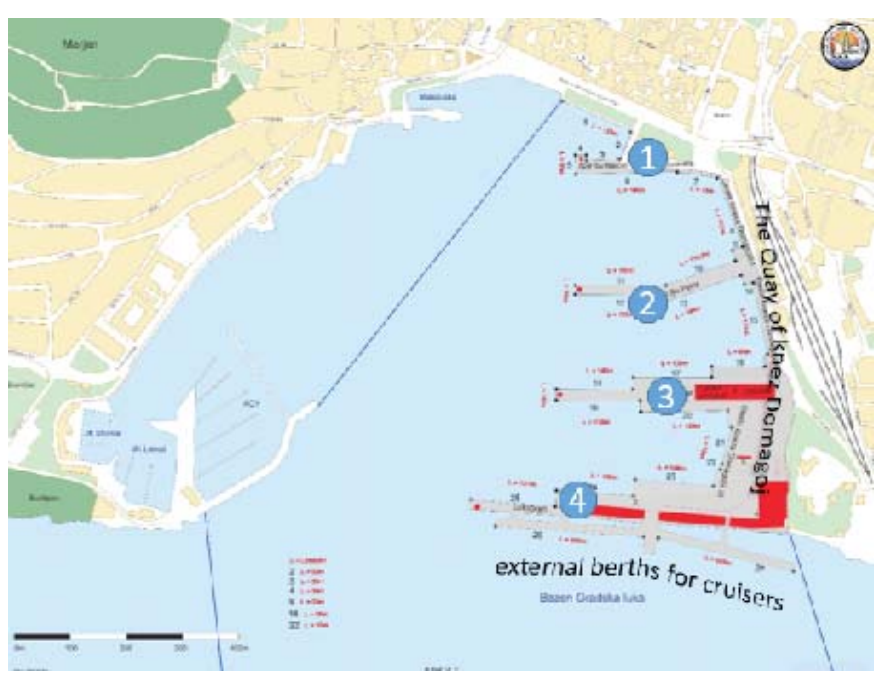

Figure 4: Port of Split

port areas in which the jurisdiction of the Port Authority Split extends, out of which one is on the north side of the town - Vranjic-Solin Basin also known as North Port in which majority of cargo transport is done. The length of operative shores of Port of Split is 3,643 meters and it is comprised of 27 berths. It can accommodate up to 320-meter-long ships with a draft up to $10.5 \mathrm{~m}$ [10].

The Port of Split is comprised of three piers that are perpendicular to the Quay of knez Domagoj, and breakwater as shown on Fig. 4. St. Nicholas' Pier mostly accommodates catamarans and motorboats. St. Peter's Pier and the Quay of Knez Domagoj generally accommodates local ferries. During summer, the Quay of Knez Domagoj is also used by smaller-sized crafts in tourism traffic and smaller yachts on cruise voyages. St Duje's Pier is mostly used by ferries and passenger ships on cruise voyages and it is a state border-crossing area. In 2017 the two external berths (berth 26 and 27) for cruisers were finished, Fig. 5.

With the length of $265 \mathrm{~m}$ and $245 \mathrm{~m}$, they are capable of simultaneously accommodating two cruise ships of 320 $\mathrm{m}$ and $270 \mathrm{~m}$ respectively.

The berths are equipped with border crossing points and sanitary facilities. An access road has been connected to the pier and other supporting infrastructure is present in order to offer high quality service to passengers.

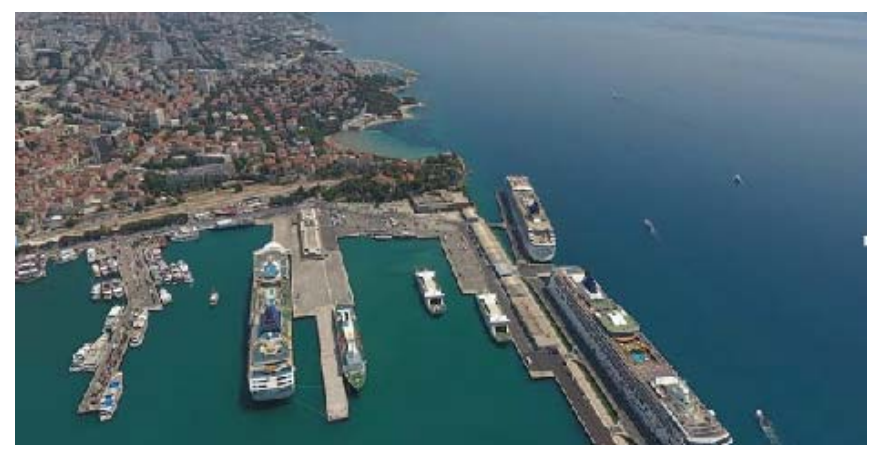

Figure 5: Cruise ships in Port of Split [10] 


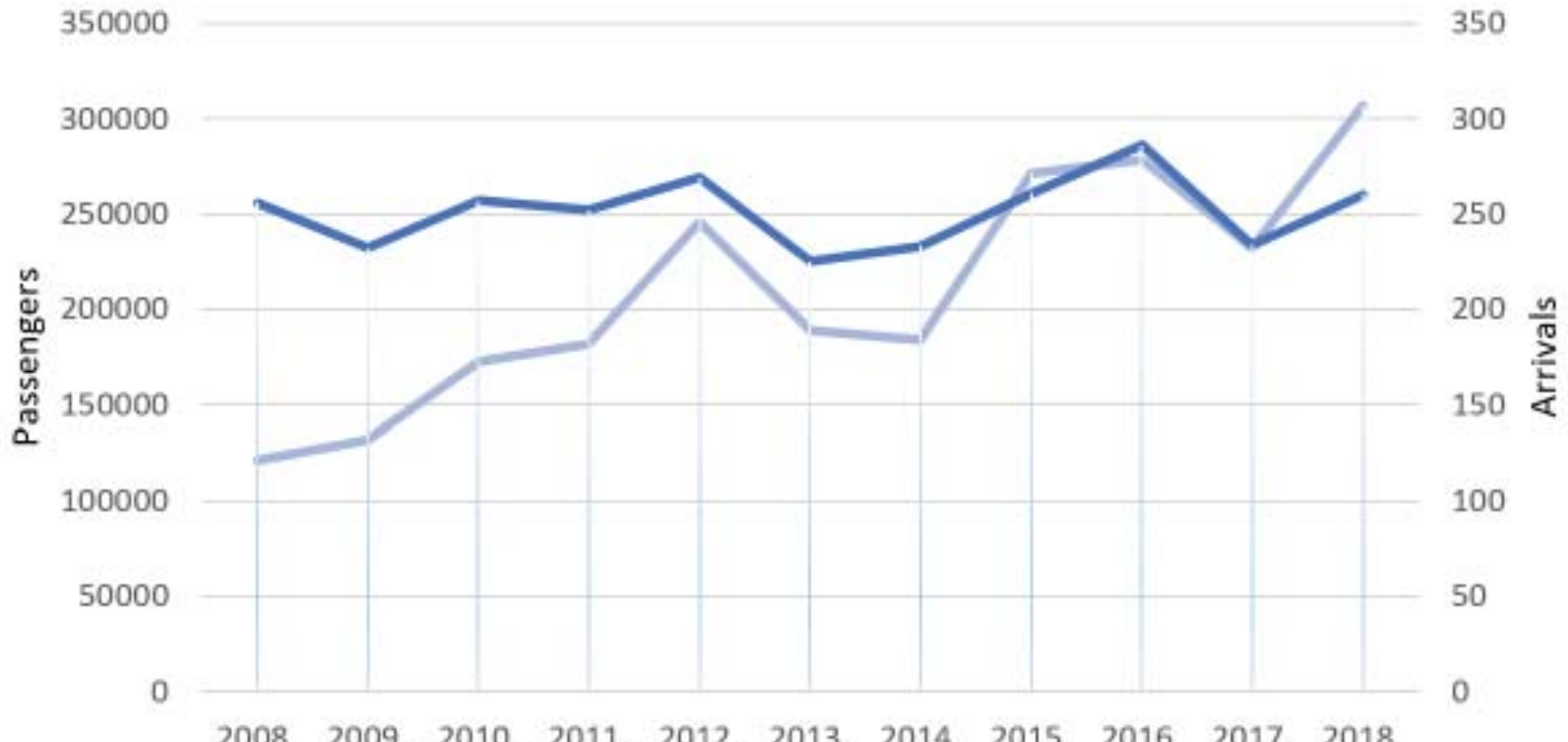

2008. 2009. 2010. 2011. 2012. 2013. 2014. 2015. 2016. 2017. 2018.

Passengers Arrivals

Figure 6: Cruise ship traffic in Port of Split in the last decade

\section{Cruise ship traffic in 10-year period}

Cruise ship traffic in Port of Split is continuously growing throughout the years. The growth trend is shown in Fig. 6 .

The overall growth of passenger traffic is 2.5 times in 2018. There was a fall in 2013, 2014 and 2017 in the number of passengers. However, the number of arrivals of cruise ships is stagnant and it ranges from 232 to 286 , with average of 251 arrivals. When comparing the number of passengers and the number of arrivals it can be concluded that with each year bigger cruise ships are coming to Port of Split. That is a world trend but in the last two years, it can also be related to newly build external berths.

That can be confirmed with announcements of arrivals for 2019 and 2020. For comparison, in 2018 there were 260 arrivals with 307,148 passengers and in 2019 there will be 284 arrivals and 305 arrivals in 2020 .

The exact number of passengers is still unknown but it can be estimated that the number of passengers will reach 350,000 .

\section{Traffic of large cruise ships in 5-year period}

When analyzing size of the cruise ships that arrived in Port of Split in 5-year period 2014-2018 it can be calculated that cruise ships with capacity less than 500 passengers (very small and small cruise ships) have in average $49 \%$ of arrivals and only $7 \%$ of passengers in total number of arrivals/passengers. So it can be concluded that in terms of passenger traffic from cruise ships in Port of Split, a good representation can be made if only large cruise ships (with capacity more than 500 passengers) are taken into a consideration. A detailed analysis of traf- fic of large cruise ships was made for 5-year period in Port of Split and the results are presented below.

Distribution of passenger traffic on large cruise ships through months is shown on Fig. 7. Maximum passenger number was in different month for each year but looking at the average September is the busiest month with 22 arrivals and 37,000 passengers. Generally, it can be concluded that passenger traffic is the biggest in six months from May to October and evenly distributed. In that period of year $84 \%$ of total passenger traffic is realized. In April and November passenger traffic is approximately twice lower and it takes up $13 \%$ of total passenger traffic. However, some changes in the distribution of traffic through months are visible. Season of large cruise ships in Port of Split lasted from April till October in 2014, it expanded to November in 2015, in 2016 and 2017 season lasted from March to December, and in 2018 it expanded throughout the entire year (February excluded) while according to announcements in $2019 \mathrm{ev}$ ery month of the year will be represented with traffic from large cruise ships.

In 5-year period 79 different large cruise ships from 24 cruise lines arrived in Split. Distribution of total number of arrivals and ships in relation to cruise lines is shown in Fig. 8.

Analysis of total number of arrivals and ships in relation to cruise lines shows that distribution of these values is uneven. Some cruise lines send several ships in Port of Split for one or two visits (like Oceania 12 ships on 17 arrivals) and some send one or two ships but on repeated arrivals (like Norwegian Cruise line 7 ships on 69 arrivals) throughout the year. Generally, Costa cruises with 31.2 and MSC Cruises with 21.4 arrivals a year in 
coos

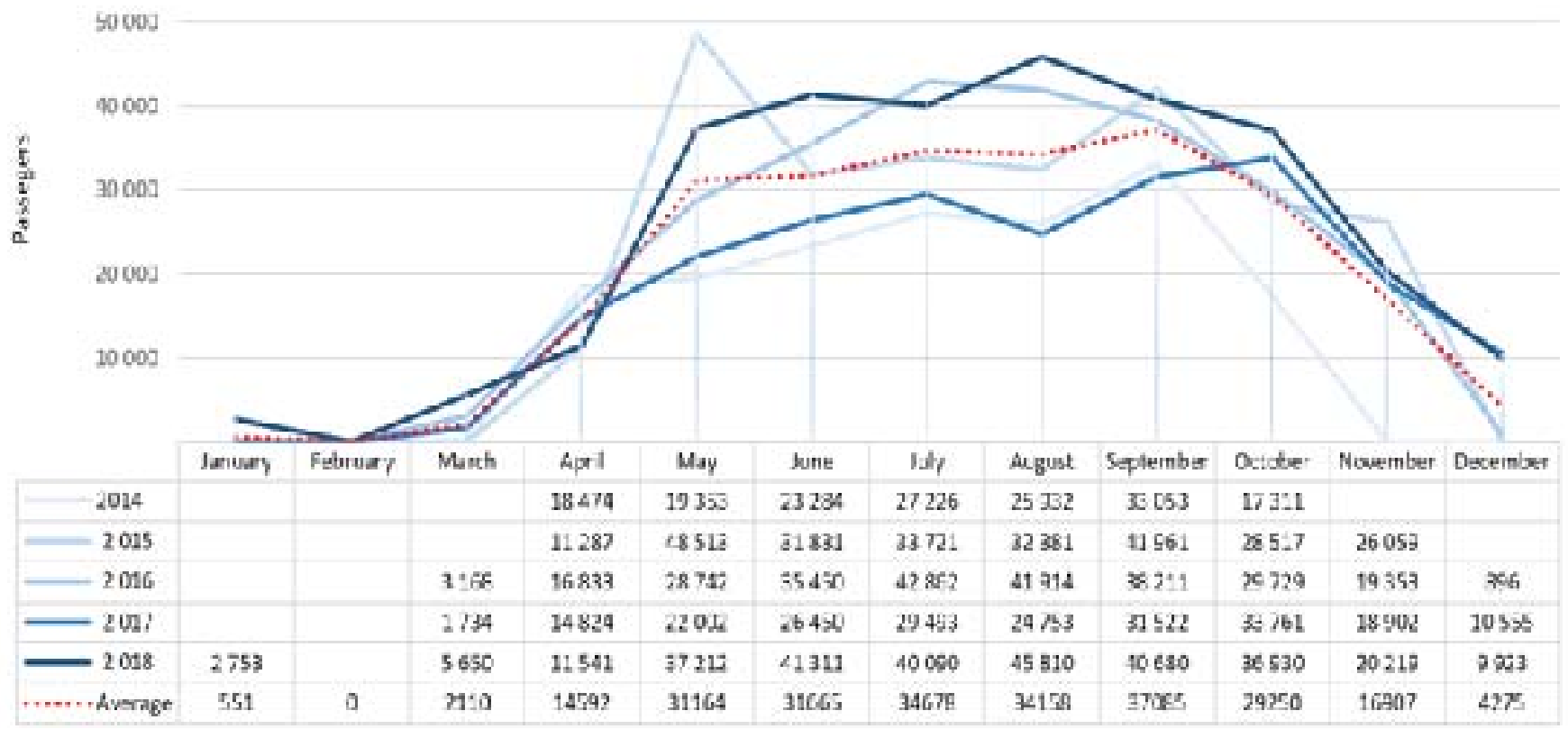

Figure 7: Passenger traffic on large cruise ships in Port of Split in 5-year period

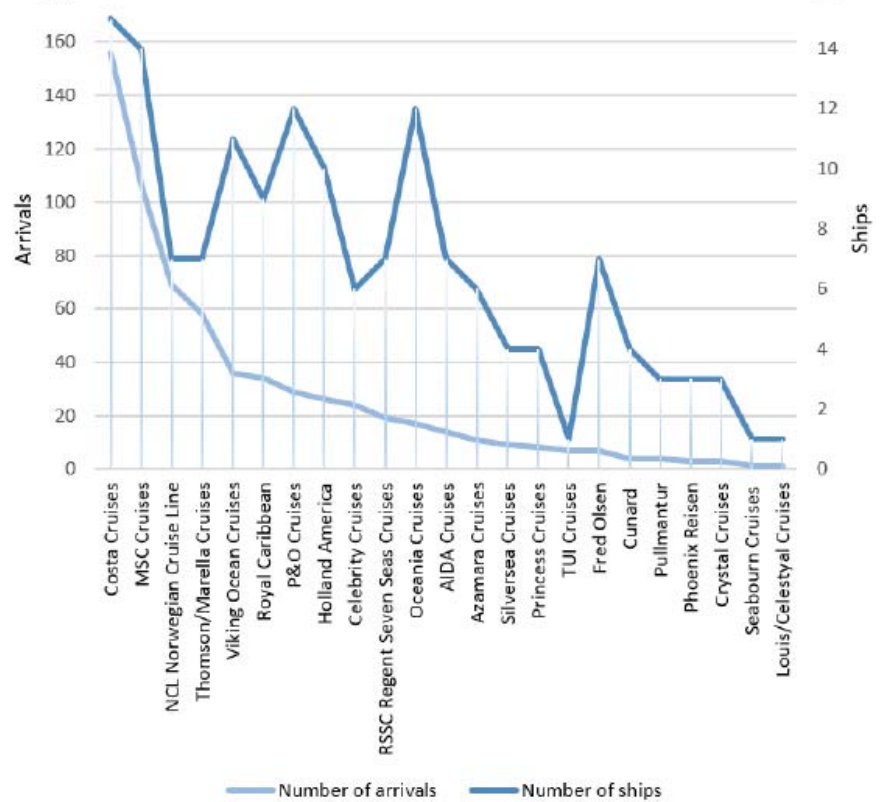

Figure 8: Distribution of total number of arrivals and ships in relation to cruise lines in Port of Split in 5-year period

average take $41 \%$ of all arrivals of cruise ships in Split.

If Norwegian Cruise Line (13.8 arrivals a year in average) and Marella Cruises (11.6 arrivals a year in average) are added with $20 \%$ of all arrivals, it means that 20 remaining cruise lines take only $39 \%$ of cruise arrivals.

In 5-year period a total of 2,364,352 passengers on large cruise ships arrived in Split. Distribution of total number of passengers in relation to cruise lines is shown in Fig. 9.

Analysis of total number of passengers in relation to cruise lines shows almost the same distribution as the

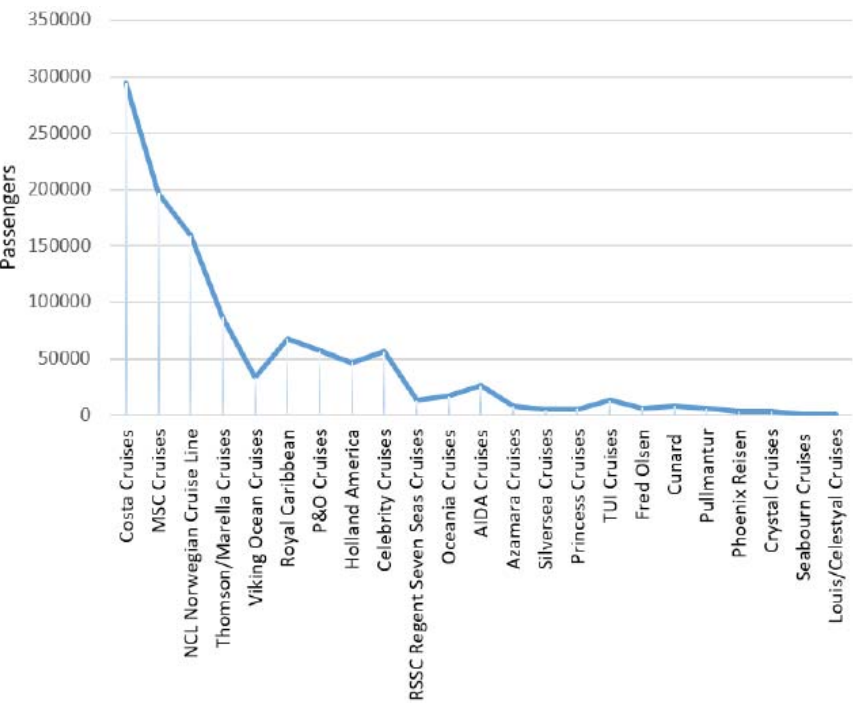

Figure 9: Distribution of total number of passengers in relation to cruise lines in Port of Split in 5-year period

number of arrivals (with exceptions like Viking Cruises and Regent Seven Seas Cruises that generally own medium size ships). Again, Costa cruises with 58,838 and MSC Cruises with 39,377 passengers a year in average take $44 \%$ of all cruise passenger traffic in Split. If Norwegian Cruise Line (31,835 passengers a year in average) and Marella Cruises (17,410 passengers a year in average) are added with $22 \%$ of all passengers, it means that 20 remaining cruise lines take only $32 \%$ of cruise arrivals. Cruise lines that send their ships to Split belong to all quality classes and are evenly distributed: six of them is in the mainstream class, eight of them in budget class, three are luxury cruise lines and five all-inclusive cruise lines. 


\section{PERSPECTIVE OF CRUISE SHIP TRAFFIC IN PORT OF SPLIT}

Today, cruising operators must meet the challenges of the market by providing a superior onboard experience, a variety of entertainment onboard but also ashore, in cruise ports, and easy transportation to and from the ship.

Port of Split has a lot to offer as a destination. The town itself has a historical core, 1700 years old, in centre of which is Diocletian Palace, one of the best-preserved monuments of the Roman architecture in the world, just 1 $\mathrm{km}$ walking distance from the external berths for cruisers.

Newly build berths are connected by a road and have other supporting infrastructure (like bus parking space) in order to offer high quality service to passengers. In proximity of Split there is a variety of excursions available for passengers, Fig. 10, from remnants of ancient town of Salona $(20 \mathrm{~km})$, Ancient town of Trogir $(20 \mathrm{~km})$, Klis fortress $(15 \mathrm{~km})$, River Cetina rafting $(30 \mathrm{~km})$ to Krka waterfalls and island of Visovac $(80 \mathrm{~km})$.

However, there are still some negative sides for cruise ships in Port of Split, but also from cruise ships to Port of Split. Negative sides of the Port are problems of crowding and congestion in the town centre, as a result of mentioned local line traffic to surrounding islands and from land tourists that visit Split. Domestic transport accounts for $91 \%$ of passengers and $89 \%$ of vehicles passing through the City Port Basin [1]. Road transport is of the utmost importance for the functioning of ferry and cruiser traffic flows [12] and in Port of Split it is still not resolved in a proper manner. A traffic problem could be partially solved by relocating international maritime transport to the North Port, so it could be replaced with cruise and passenger ships, transforming the port into a solely passenger port. Also, a relocation of lines with trucks for islands' provision could relieve some pressure from the centre traffic. As for negative sides of cruise ships, a literature is full of examples. Cruise tourism represents a high environmental impact activity with a global presence and rapid growth. It raises concerns due to its tendency of being environmental unsustainable [13]. Cruise ships represent less than $1 \%$ of the global merchant fleet yet it has been estimated that they are responsible for $25 \%$ of all waste generated by merchant vessels [14]. Cruise ships undoubtedly have negative impact on the environment: land, sea and air. Cruise emissions cover a multitude of organic and inorganic wastes in gaseous, liquid and solid forms, from solid waste [15], hazardous waste [16], bilge water, ballast water [17] [18], sanitary wastewater [19] to [21], food waste, ash from incinerators [22], biocides [23] and arange of emissions to the atmosphere like nitrogen, sulphur and carbon oxides (NOx, SOx and COx), and floating particles [24][25]. Cruise ships also bring to the recipient country lots of benefits. The goal is to find a perfect equilibrium between the two, to ensure that the cruise tourism in Port of Split is developing in terms of sustainable development.

\section{CONCLUSION}

Cruising tourism is a growing industry with an increasing number of ships and their capacities, proven by the cruise ship order book in which an average capacity of 50 new cruise ships is 4000 passengers. At the same time, smaller and older ships are going out of work. Cruise traffic in Port of Split is in continuous growth, both in the number of arrivals and passengers. All major cruise lines send their ships to Split and season of cruise ships in Split has expanded throughout the year. With two new berths Split can accommodate three large cruise ships at the same time, so there is still room for further growth as it is suggested by cruise announcements for 2020 . However, Port of Split, as a second largest cruise destination in Croatia must evaluate the carrying capacity of their cruise traffic in terms of sustainable development for which this paper gives a good basis.
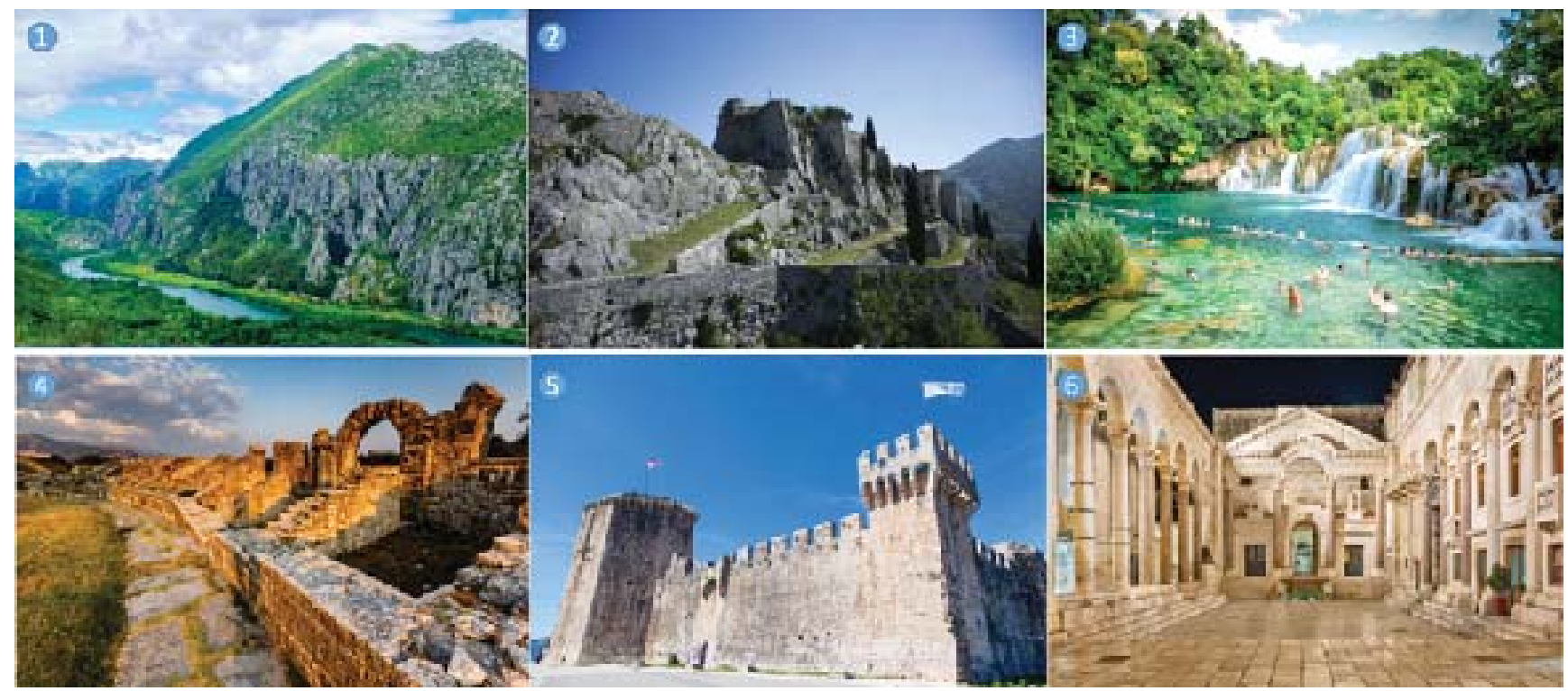

Figure 10: Excursions available for cruise passengers in Port of Split [10] 


\section{ACKNOWLEDGEMENTS}

We thank Split Port authority for data about cruise ship traffic in the Port of Split for the last decade.

\section{REFERENCES}

1. Dundović, Č., Jurić, M.\& Kovačić, M. (2013). Optimizing the Split port system to promote sustainable development. Pomorstvo - Scientific Journal of Maritime Research, vol. 27, no. 2, 285-298.

2. Zanne M. \& Beškovnik, B. (2018). Assesing Home Port Potential of Selected Adriatic Ports.TOMS Transactions on Maritime Science, vol. 7, no. 2, 143153, DOI: 10.7225/toms.v07.n02.004

3. Blue water Network \& Friends of the Earth. Ship air pollution, from: http://www.foe.org/projects/oceansand-forests/cruise-ships, accessed on: 2010-02-20.

4. CLIA - Cruise Lines International Association. 2019 CLIA State of Cruise Industry Report, from: http:// cruising.org, accessed on: 2019-05-25.

5. FCCA (2018). Cruise Industry Overview 2017: State of the Cruise Industry. Pembroke Pines: Florida-Caribbean Cruise Association.

6. Med Cruise Association. Cruise Activities in Med Cruise Ports - 2017 statistics, from:http://www.medcruise.com/sites/default/files/2018-03/cruise_activities_in_medcruise_ports-statistics_2017_final_0. pdf, accessed on: 2019-06-28.

7. Institute of shipping economics and logistics. Shipping statistics and market review, vol. 54, from: http:// www.isl.org, accessed on: 2011-09-07.

8. Perić, T. \& Račić, N. (2019). Cruise ship traffic in the Adriatic Sea: Environmental impact. 8thInternational Maritime Science Conference (IMSC 2019), p. 49-58.

9. Cruise Mapper. Cruise ship passenger capacity, from: https://www.cruisemapper.com/wiki/761-cruise -ship-passenger-capacity-ratings, accessed on: 2019-05-17.

10. Split PortAuthority. Port of Split, from: https://portsplit. hr/en/port-of-split/, accessed on: 2019-05-03.

11. Avoid Crowds. Europe's busiest cruise ports in 2019 , from: https://avoid-crowds.com/europe-busiestcruise-ports-in-2019/, accessed on: 2019-06-15.

12. Čokorilo, O.\& Čavka, I. (2015). The role of air transport development in Adriatic-Ionian microregion. International Journal for Traffic and Transport Engineering,vol. 5, no. 4, 344-359, DOl:10.7708/ ijtte.2015.5(4).01

13. Carić, H. (2015). Challenges and prospects of valuation - cruise ship pollution case. Journal of Cleaner Production, Elsevier, vol. 111 (B), 487-498, DOI: 10.1016/j.jclepro.2015.01.03
14. Butt, N. (2007). The impact of cruise ship generated waste on home ports and ports of call: A study of Southampton. Marine Policy, Elsevier,vol. 31, no. 5, 591-598, DOI: 10.1016/j.marpol.2007.03.002

15. Slišković, M., Ukić, H. \& Božić, K. (2016). Assessment of Solid Waste from Cruise Ships in the Port of Split. TOMS - Transactions on Maritime Science, vol. 5, no. 2, 155-160, DOI: 10.7225/toms.v05.n02.006

16. Klein, R. A. (2000). Cruising - out of control: the cruising Industry, the environment, workers, and the Maritimes. Canadian centre for policy alternatives Nova Scotia.

17. Copeland, C. (2008). Cruise ship pollution: background, laws and regulations, and key issues. Congressional research service.

18. International Maritime Organization. International convention for the control and management of ships' ballast water and sediments (BWM),from: https:// www.imo.org, accessed on: 2019-06-15.

19. Perić,T. Komadina, P. \& Račić,N. (2016). Wastewater pollution from cruise ships in the Adriatic Sea. Promet - Traffic\&Transportation, vol. 28, no.4,425433, DOI:10.7307/ptt.v28i4.2087

20. Perić, T. (2016). Waste water pollution from cruise ships in coastal sea area of the Republic of Croatia. Pomorstvo - Scientific Journal of Maritime Research, vol. 30, no. 2, 160-164, DOI: 10.31217/p.30.2.9

21. T. Perić, Mihanović, V. \&Račić, N. (2019). Evaluation model of marine pollution by waste water from cruise ships. Brodogradnja, vol. 70, no. 3, 79-92, DOI: $10.21278 /$ brod70305

22. Mackelworth,P. (2014). Cruise tourism environmental impacts - the perspective from the Adriatic Sea. Ocean \& Coastal Management, vol. 102, 350-363, DOI: 10.1016/j.ocecoaman.2014.09.008

23. Carić,H.,Klobučar,G. \& Štambuk, A. (2016). Ecotoxicological risk assessment of antifouling emissions in a cruise ship port. Journal of Cleaner Production, vol. 121, 159-168, DOI: 10.1016/j.jclepro.2014.08.072

24. Hall, C. M., Gossling, S.\& Scott, D. (Eds.). (2015). The Routledge handbook of tourism and sustainability. Routledge.

25. Murena, F.,Mocerino,L., Quaranta,F.\&Toscano, D. (2018). Impact on air quality of cruise ship emissions in Naples, Italy. Atmospheric Environment vol. 187, 70-83, DOI: 10.1016/j.atmosenv.2018.05.056

Paper submitted: 13.07.2019.

Paper accepted: 24.08.2019.

This is an open access article distributed under the CC $B Y-N C-N D 4.0$ terms and conditions. 